\title{
En Grundtvig-salme teologisk fortolket
}

\section{Af Theodor Jørgensen}

I artiklen fremlægges en påstand om, at uden en teologisk-dogmatisk læsning af Grundtvigs salmer er en tolkning af dem ikke fyldestgørende, og der argumenteres for påstanden ved hjælp af en dogmatisk læsning af Grundtvigs julesalme "Velkommen igjen, Guds Engle smaa".

Hensigten med denne artikel er et forsvar for teologiske læsninger af salmer i det hele taget og af Grundtvigs salmer i særdeleshed. Og jeg har endda lyst til at skærpe den yderligere og tale om en dogmatisk læsning og tolkning.

Imod en sådan læsning gøres flere indvendinger gældende: 1 . Salmetekster er litterære tekster, ikke dogmatiske. 2. Salmetekster er udtryk for fromhedslivet og som sådan subjektive. 3. Salmer er liturgiske tekster. De hører hjemme i gudstjenestesammenhæng. De er brugstekster.

Hvad den første indvending angår, så kan det ikke nægtes, at salmer primært er litterære tekster, men det udelukker ikke en dogmatisk læsning. De er ikke dogmatiske tekster i betydning af at være autoritative tekster som de oldkirkelige bekendelser eller Confessio Augustana. Men de har som salmer dogmatiske indhold, hvilket allerede fremgår af den kendsgerning, at de kan indordnes i forskellige afsnit af salmebogen, der er struktureret efter kirkeåret og bekendelsen, dog også det kristne liv. Allerede en sådan indordning kræver, at man gør sig tanker om, i hvilket afsnit de bedst hører hjemme.

Noget tilsvarende kan siges til den anden indvending, at salmetekster er udtryk for fromhedslivet, for den subjektive side af troen. $\mathrm{Nu}$ er tro jo ikke tro på hvad som helst. Den subjektive side er altid måske mere eller mindre tydeligt - relateret til et bestemt trosindhold og kan kun tolkes ud fra denne relation. Så man slipper ikke for en dogmatisk læsning.

Og endelig er det da rigtigt, at salmer er liturgiske tekster og indgår for det meste $\mathrm{i}$ en gudstjenestesammenhæng. Men det er snarere et argument for den dogmatiske læsning, idet bekendelse, dåb og nadver indgår som væsentlige led i gudstjenesten, som salmerne knytter sig til.

Dermed vil jeg på ingen måde afvise den litterære læsning af salmerne. Tværtimod. Det ville da også være dumt. Men den litterære 
læsning kommer ikke i mål uden den dogmatiske, da sidstnævnte kan give overraskende indfaldsvinkler til det poetiske billedsprog.

Derimod vil jeg forsvare, at en historisk og en biografisk læsning af salmerne kommer i anden række. Interesserer man sig for en salmedigters liv og virke, må salmerne selvsagt også inddrages i tolkningen af dette livsløb. Men hvad digteren muligvis selv har lagt ind i sin salme af tolkning, kan aldrig være bindende for eftertiden. Da gælder det samme for salmen som for enhver anden tekst, at den lever sit selvstændige liv, når den har forladt forfatterens pen. Forfatteren kan ikke tage patent på, hvordan den tekst kan og skal tolkes. Tolkningen må forholde sig til de tolkningsmuligheder, som teksten i sig selv frembyder. Dermed vil jeg selvfølgelig ikke udelukke, at også en historisk, biografisk indfaldsvinkel på en salmetekst kan være uddybende for dens tolkning, men bindende kan den ikke være.

Grundtvigs salmer frister til en dogmatisk læsning. Det er en generel erfaring med Grundtvigs teologi, at de mest præcise bestemmelser og formuleringer af den findes $i$ hans salmer, ofte forbundet med en ufattelig stor poetisk skønhed. Grundtvigs teologi kan karakteriseres som en poetisk teologi. For bare at nævne et enkelt eksempel, de indledende linjer til hans vel nok mest kendte pinsesalme (Grundtvig 1853, 134):

I al sin Glands nu straaler Solen,

Livs-Lyset over Naadestolen,

Nu kom vor Pindselilje-Tid,

$\mathrm{Nu}$ har vi Sommer skiær og blid (...)

Det er naturpoesi i klang, rytme og ordvalg, som ikke kan gøres bedre. Og samtidig lykkes det Grundtvig allerede i de to indledende vers at alludere til Kristus som sol victor, den sejrende sol, et gammelt Kristus-symbol, endvidere til indledningen af Johannes-evangeliet om Ordet, der var i begyndelsen, var hos Gud og var Gud. "I ham var liv, og livet var menneskenes lys" (Joh 1,4). Og endelig til Kristus som forsoneren med ordet "Naadestolen", en alludering til Rom 3,25, der i den nutidige oversættelse lyder: "Ham [dvs. Kristus] gjorde Gud ved hans blod til sonoffer ved troen", hvor der tidligere stod 'nådestol' i stedet for 'sonoffer', men med samme betydning. Det er genialt gjort. Men har man ikke denne dogmatiske læsning af de indledende vers med, ville læsningen være ufuldkommen.

Dogmatikken i Grundtvigs salmer karakteriseres bedst som et dogmatisk univers. Grundtvig digter horisontalt og vertikalt, han digter i rum og tid. Himmel, jord, dødsriget, datid, nutid, fremtid, alle disse dimensioner svinger med i så godt som alle hans salmer. Hver salme skaber et dogmatisk rum og udgør et univers, og det aftegner sig kun, når man forholder sig til hele salmen. Det er ud fra denne læsestrategi, 
at jeg vil indlade mig på en dogmatisk læsning af salmen "Velkommen igjen, Guds Engle smaa", der forhåbentlig også holder litterært.

Strofe 1 aftegner allerede dette univers: "Velkommen igjen, Guds Engle smaa." Hvad der skete for hyrderne på Betlehems mark, skal gentage sig her og nu, som det gentager sig hvert eneste år ved juletid. Og engle er for Grundtvig forbindelsesled imellem Gud og mennesker, mellem himmel og jord. Det vrimler med engle i Grundtvigs salmer. Der sættes i strofen lys og farver på rummet, der skabes af englenes komme. Englene har solskinsklæder på. Hvad ellers? De kredser jo i Himlen om Kristus, den sejrende sol. Lyset i englenes solskinsklæder står i kontrast til jordens skyggedale. Det er mørkt ved vintertide, men der er også mørkt i menneskesindet ved vintertide. "Trods klingrende Frost" - det lægger Grundtvig mere i end en temperaturangivelse. Om nogen kender Grundtvig til "Hjertets Haardhed, Hjertets Kulde". Og til dvalen, der ikke kun gælder fugl og sæd, men også menneskesindet. Strofe 1 åbner for et længslens og håbets perspektiv på trods af den fastlåsthed, som frosten sørger for. Englene spår godt år, en spådom ikke blot om et godt nytår lig med en ny og bedre fremtid, men om udbredt frugtbarhed og en god høst. ${ }^{1}$ Og ligesom Grundtvig så godt som altid medtænker et eskatologisk perspektiv i længslen og håbet, således også i høsten. ${ }^{2}$

Men englene må gøre ophold for en lille stund, for at håbet kan opretholdes. Strofe 2 fastholder den vinterlige sindsstemning fra strofe 1: "under Sky", "Paa Snee", "ved Midnats-Tide". Udtrykket "paa Kirke-Sti" kan virke forvirrende. Er det kirkehuset, hvis dør englene ikke må gå forbi og ikke må bære julen ud fra, måske i forbindelse med en midnatsmesse? Udelukkes kan det ikke, men julemidnatsmesser var vel ikke almindelige i København på Grundtvigs tid, og fra strofe 4 kan der ikke herske tvivl om, at det er hjemmets dør, som Grundtvig tænker på i første omgang, medens strofe 3 kan tolkes i begge retninger. For han kan også omtale kirken som den lave hytte (jf. fx str. 8 og 10 i salmen "Tør end Nogen ihukomme", GSV I, nr. 13, 62). Grundtvig tænker og digter i flere rum. Salmen er en menighedssalme, en vi-salme. Den er tænkt til julemorgens højmesse. Grundtvig skal have læst den op første gang i 1825 eller muligvis i 1824 ved netop denne gudstjeneste. ${ }^{3}$ Kirkerummet som menighedens rum er tænkt med, men også hjemmet og ligeledes sjælens indre rum. Salmen bevæger sig på det kollektive og det individuelle plan, og sådan må det også være med en salme. Strofen rummer en angst for ikke at få besøg af englene, ikke at få del i juleglæden med en sindets kvide til følge.

Denne angst hænger sammen med en frygt for ikke at være værdig til englenes besøg: "Vor Hytte er lav og saa vor Dør, / Kun Armod er 
derinde”. Den lave og fattige hytte. Det kan som nævnt gå på kirkebygningen, og da har Grundtvig også tænkt på kirken som Jesu Kristi kirke, på kirken som bygget af levende sten, som menighed, hvis tilstand er fattig, så den ikke kan leve op til så fint et besøg. Denne dobbelte betydning spiller fx hele den anførte salme "Tør end Nogen ihukomme" på. Og da får også "Kruset af Leer, og Kagen tør" en dobbelt betydning, den bogstavelige som tegn på konkret fattigdom og den teologiske i form af nadveren. Da kan det slet ikke undre, at engle finder sig deri. For Jesus selv er til stede i det fattige måltid. Som de også fandt sig i at besøge hytten i Betlehem, selv om den var fattig, men den rummede Jesusbarnet, og det englebesøg dengang holder digter-viet og dermed menigheden sig til i tillid til og forventning om, at englene vil gentage besøget. Men også det enkelte menneske kan erfare sin personlige tilstand som så fattig, at det ikke kan leve op til så fint et besøg. Hytte-billedet kan omfatte den enkelte: "Kom Jesus! vær vor Hytte-Giæst! / Hold selv i [NB] os din Jule-Fest!'(GSV I, nr. 193, 398 , str. 19). Hjertet som krybberum for Jesus er udbredt i salmelitteraturen.

De første tre strofer følger en struktur, som også kendes fra de gammeltestamentlige salmers påkaldelse af Gud, en appel til Gud om hans komme, her i englenes skikkelse som hans budbringere, forbundet med en påmindelse af Gud, hvad han har gjort før, hans adfærd mod fædrene, som skal give appellen vægt. ${ }^{4}$ Englenes bevægelse oppefra modsvares af bønnens bevægelse nedefra, der søger at fastholde det himmelske besøg, velvidende, at det har mennesket ikke i sin magt. For Guds nærvær bestemmes af Gud selv, når og hvor Gud vil det.

I strofe 4 skifter salmens stemthed karakter. Det er børnene i hjemmets senge, og dem er der ikke knyttet vinterbilleder til. Nej, de gror som blomster i enge. Kontrasten mellem voksensindet og barnesindet bliver tydeligt. Og voksen-viet beder om, at englene skal synge for børnene, som lærken synger og slår sin trille, når den flyver op imod himlen. Igen et forårsbillede. Og englesangen skal være af en art, som de længe ikke har hørt! Englenes nedadgående bevægelse modsvares nu af en opadgående bevægelse. Englene skal med deres sang løfte børnene mod himlen.

Men hvem er børnene? Uden tvivl børn i ganske konkret forstand. Dog hvorfor skal englene specielt synge for dem og ikke for de voksne, omfattet af salmens vi? Er børnene måske også barnet i enhver voksen, som englene skal synge for, synge en himmelsk sang, som deres frostbundne vintersind længe ikke har hørt? I en version fra 1848 lyder det sidste vers: "som hørt $v i$ har ei længe" (jf. GSV VI, 74. Kursiveringen er min). 
Konsekvensen af denne englesang beskrives i strofe 5. Børnene kommer til at drømme. Det er det sovende barn, der hører englenes sang. Det er ikke vågnet endnu. Og børnenes drøm har Betlehem som indhold, det guddommelige barns hjem i krybberummet. Drømmen er ikke klar endnu, den er forblommet, men den er sand. Det er en drøm om stedet, hvor Ordet lod sig føde, skaberordet, det, som var fra begyndelsen, det Ord, der er Gud. Her begyndte Gud sit menneskeliv iblandt os, her tog inkarnationen skikkelse. Og drømmen udvikler sig til leg, en sorgløs leg med de engle, hvis sang de har hørt, og som har åbnet deres drømmende øjne. Man må vel forestille sig, at drømmelegen med englene foregår i selve krybberummet, altså omkring Jesusbarnet. Legens bevægelse står i modsætning til de indledende strofers fastlåste stemthed. ${ }^{5}$

I strofe 6 følger så opvågningen til bevidsthed om opfyldelse, der står lige for døren. Man behøver ikke længere at tælle timer. Og den kimende kirkeklokke indicerer, at vi er på vej til julemorgens højmesse. Men det er stadigvæk børnene, der udgør denne strofes subjekt. Og i den version, som Grundtvig optager i Sang-Varket i 1837 (GSV I, nr. 197, 406), lyder strofens 3. og 4. vers: "Da nynne de Jule-Sang paany, / Der sig med Hjertet rimer." Det er endnu ikke den fuldtonende sang. Den kommer senere. Alligevel er det en julesang, der rimer med hjertet $\mathrm{i}$ dets længsel efter juleglæden, længes efter at komme ud af sin dvaletilstand. Men så er vi allerede ovre i de voksnes rækker. Og at de er tænkt med af Grundtvig fra begyndelsen, tyder den variant på, som findes i 1830-udgaven af Christelige Prcedikener eller Søndags-Bog (Grundtvig 1830, 98-99) Dér lyder versene: "Da høre vi Psalmen, som paa Ny / Sig ret med Hjertet rimer." Og dette er fastholdt i 1860-udgaven samt i de forskellige udgaver af L. C. Hagens Historiske Psalmer og Riim. En anden variant findes i manuskriptet (i Fasc. 383) til Kirke-Psalmer udgivne til Prøve og lyder: "Da høre vi Psalme-Nyn paany." Men i trykket fra 1845 af dette prøvehefte findes verset sådan, som det også står i Den Danske Salmebog i dag: "Da høre vi julesang på ny, / som sig med hjertet rimer." Børnenes julesang eller psalme-nyn rimer sig med voksenhjertets længsel. Efter at blive barn på ny? Og nu klinger det ifølge $G S V$-udgaven fra 1837 "sødt fra Morgen-Sky, / Naar Kirke-Klokken kimer!" Her gentages den samme bevægelse fra oven og nedefter, som vi finder i de første to strofer, englenes bevægelse, signaleret af klokkens kimen. Men i alle håndskrifterne finder vi den version, som også står at læse i Den Danske Salmebog: "Da klinger det sødt $\mathrm{i}$ højen sky, / når juleklokken kimer." Ikke mere "under Sky", som i strofe 2. Bevægelsen opad lykkes! ${ }^{6}$ 
Strofe 7 er opfyldelsens strofe. Bevægelsen fra himmel til jord kaldte på bevægelsen fra jord til himmel. Englene lærte børnene at nynne julesang, og den voksne fik ved børnenes hjælp julesangen ind $\mathrm{i}$ hjertet og kan nu deltage i salmesangen og sammen med børnene skabe den tonestige, som englene kan vandre op og ned ad. Bevægelsen går begge veje, Himlen forenes med jorden, og det sker ved, at menigheden sidder og synger denne salme. Selve salmen "Velkommen igjen, Guds Engle smaa" bliver sin egen opfyldelse i og med, at den synges. Et evighedens hic et nunc. Kristus selv kommer til stede og byder Guds fred til dem, som længes og higer efter den. "Søg først Guds rige og hans retfærdighed, da skal alt det andet gives jer i tilgift" (Matt 6,33). Overvejende har man i tolkningen af denne salme forstået "vor Herre" som lig med Gud Fader, men burde der så ikke have stået 'Vorherre'?' Vi ved, at Grundtvig lagde stor vægt på fredshilsenen som et af Jesu egne mundord, den hilsen, som var de første ord, han som opstanden mødte sine skrækslagne disciple med (Joh 20,19). ${ }^{8} \mathrm{Og}$ det er nærliggende for Grundtvig at knytte påsken til julen, han, som $\mathrm{i}$ salmen "Denne er Dagen, som Herren har gjort!" i tredje strofe, der i stemthed i den grad minder om strofe 7 her, kan synge "Paaske og Pindse udsprang af Juul" (GSV I, nr. 134, 305). Med den fredshilsen åbnes Himlens borgeled nu. Der er ikke længere en lukket Himmel, ikke mere en sky, der stiller sig imellem Gud og mennesker. Nej, Guds rige kommer og er midt iblandt den syngende menighed og vel også inden $\mathrm{i}$ hver enkel gudstjenestegæst $\mathrm{i}$ og med, at Kristus selv byder Guds fred til den enkelte, der længes efter den. Længslen udspringer af hjertet.

Med strofe 8 sker der et stil- og stemningsskifte. ${ }^{9}$ Strofen er en bøn til Gud, til "Vor Fader i Himlen!" Stemningsskiftet består i, at den glæde, der fuldt tonende var til stede i strofe 7, nu er fraværende. I stedet er der smerte, og det på grund af julesorgen eller, som det hedder i 2. udgave af Søndags-Bog (III, 1860, 88), "Advents-Sorgen" [etc.], uden at det angives nærmere, hvad den er en sorg over. Det er et fantastisk godt greb fra Grundtvigs side, som man finder i flere af hans salmer, når de imod slutningen har en højstemt tone. Så forsøger han med den sidste strofe at hente tvivleren eller den nedslåede ind og giver ham dermed også plads i salmen. Strofens 'vi' beder om at få den juleglæde at se, som ifølge strofe 7 er til stede, men som de ikke endnu kan, men gerne vil se, inden de dør. Det vil nemlig føre til, at en smerte i dem, der kan sammenlignes med en fødende kvindes veer, vil "sødt bortvugges". Noget skal altså fødes i dem, eller rettere genfødes. Hvad det er helt præcist, siges ikke. Er det barnet, der har sans for englenes sang, der evner at drømme sandt om Betlehem og derfor bliver i stand til selv at nynne julesang, der skal genfødes i os, så at 
julesorgen må blive slukket og juleglæden må indfinde sig? Eller er det Jesus selv som juleglæden i egen person, så at hjertet bliver krybberum for ham? Med billedet af den fødende mors veer alluderer Grundtvig til Joh 16,19 $\mathrm{ff}^{10}$ Her taler Jesus til disciplene om sin bortgang og om den sorg, der da vil ramme dem: "I skal sørge, men jeres sorg skal blive til glæde. Når kvinden skal føde, har hun det svært, fordi hendes time er kommet; men når hun har født sit barn, husker hun ikke mere sin trængsel af glæde over, at et menneske er født til verden. Også I sørger nu, men jeg skal se jer igen, og da skal jeres hjerte glæde sig, og ingen skal tage jeres glæde fra jer." Sorgen er her sorgen over Jesu fravær, og glæden er glæden over hans nærvær.

Der er gjort mange tolkninger af, hvad indholdet er af denne julesorg. For mig at se ligger meningen lige for i forlængelse af spillet mellem barn og voksen i hele salmen, hvor det er barnet, der forløser voksensindet til juleglæden og julesangen, så at Guds rige kommer med Kristus. I Grundtvigs dogmatiske univers spiller beretningen om Jesus, der velsigner de små børn (jf. Mark 10,13 ff.), en stor rolle. Han kaldte den for barneevangeliet og knyttede den tæt til dåben. Her siger Jesus til de voksne: "Sandelig siger jeg jer: Den, der ikke modtager Guds rige ligesom et lille barn, kommer slet ikke ind i det." Julesorgen er sorgen over endnu ikke at have magtet at blive barn på ny, ikke at have kunnet integrere barnet i sig, der er i stand til at gå ind i Guds rige eller modtage det. Og tænker man på, hvilken rolle barnedåben spiller i Grundtvigs dogmatiske univers, som han forbinder med en genfødsel af Jesus i os, for at kristenlivet må forme sig som en Kristusvækst, hvor Kristus vokser i os, ${ }^{11}$ da kan julesorgen også tolkes som den voksnes sorg over ikke at have integreret den Kristus i sit sind, som i dåben er genfødt i ham. Det kunne varianten "Advents-Sorgen" tyde i retning af.

Det geniale ved denne salme er for mig at se det, at og hvordan den magter at integrere vi og jeg, det kollektive og det individuelle, den voksne og barnet, hvilket gør, at salmen evner at inddrage mange forskellige jeger i sig. Og det er vel det bedste, man kan sige om en salme, især når den så samtidig med sin himmel-til-jord og jord-tilhimmel bevægelse integrerer det guddommelige og det menneskelige.

Er nu denne tolkning så dogmatisk, som den gav sig ud for at være? Er den ikke lige så meget psykologisk og eksistentiel? Vist er den så, og jeg håber da også, at den holder litterært. Men det udelukker ikke en dogmatisk tolkning. Det kræver den tværtimod, når det drejer sig om en salme, der i den grad er udsprunget af en erfaringsteologi som Grundtvigs. Det geniale i Grundtvigs salmedigtning som i hans teologi i det hele taget er, hvordan han evner at fylde dogmatiske strukturer og dogmatisk indhold med menneskelig livserfaring og 
dermed er en inkarnationsteolog af rang både i sin skabelsesteologi og sin soteriologi. "Velkommen igjen, Guds Engle smaa" er en inkarnationspoetisk salme om Ordet, der blev kød og tog og stadig tager bolig iblandt os og i os.

\section{Forkortelser}

Fasc.: Fascikel, dvs. håndskriftskapsel i N.F.S. Grundtvigs Arkiv på Det Kongelige Bibliotek.

GP I-XII: Chr. Thodberg (udg.) (1983-86), Grundtvigs Prcedikener 1823-24, bind 1-12, København.

GSV I-VI: Th. Balslev et al. (1944-64), Grundtvigs Sang-Verk. Samlet Udgave, bind 1-6, København.

SJ I-IV: Steen Johansen (1948-54), Bibliografi over N.F.S. Grundtvigs Skrifter, bind 1 (indtil 1836), bind 2 (1837-49), bind 3 (1850-72), bind 4 (Rettelser og Tilføjelser. Register), København.

US I-X: Holger Begtrup (udg.) (1904-09), Nik. Fred. Sev. Grundtvigs Udvalgte Skrifter, bind 1-10, København.

\section{Litteraturliste}

\section{Værker af Grundtvig}

Balslev, Th. et al. (1944 og 1964), Grundtvigs Sang-Vark. Samlet Udgave, bind 1, 4 og 6, København.

Begtrup, Holger (udg.) (1909), Nik. Fred. Sev. Grundtvigs Udvalgte Skrifter, bind 8, København.

Grundtvig, N. F. S., Fasc. 383.

- (1830), Christelige Prodikener eller Søndags-Bog, III, København; 2. udgave 1860, København.

(1836-37) ["Sang-Værk til den danske Kirke"] i Collinske Samling $2208^{\circ}, 59$ r-v, Det Kongelige Bibliotek, København.

(1837), "Denne er Dagen, som Herren har gjort!" i GSV I, 304305.

— (1837), "Det kimer nu til Jule-Fest" i GSV I, 395-398.

— (1837), "Hil dig, Frelser og Forsoner" i GSV I, 455-457.

- (1837), "Tør end Nogen ihukomme" i GSV I, 60-63.

— (1840-42), "Kirkelige Oplysninger især for Lutherske Christne" i US VIII, 370-457.

_ (1844), "Nu falmer Skoven trindt om Land" i GSV IV, 50-51.

- (1850), Fest-Psalmer, nye oplag og udgaver 1851, 1852, 1853, 1854, 1856, 1864, 1868, 1870.

_ (1853), "I al sin Glands nu straaler Solen" i Fest-Psalmer, 5.oplag, København, 134-135. 
Hagen, L. C. (udg.) (1832), Historiske Psalmer og Riim til BørneLardom, nye udgaver 1840, 1843, 1848 og 1856.

Johansen, Steen (1948-54), Bibliografi over N. F. S. Grundtvigs Skrifter, bind 1 (indtil 1836), København.

Thodberg, Chr. (udg.) (1983), Grundtvigs Prcedikener 1823-24, bind 2, og Grundtvigs Pradikener 1824-25, bind 3, København.

\section{Værker af andre forfattere}

Dam, Poul (1995), "En skillestreg" i Hymnologiske Meddelelser, 24. årg. august $1995 \mathrm{nr} .2$, 134-135.

Den Danske Salmebog (1953). København.

Den Danske Salmebog (2004). København.

Kjærgaard, Jørgen (2002), Salmehåndbog, II. København.

Koch, L. J. (udg.) (1951), Hans Adolph Brorson. Samlede Skrifter, I, København.

Ludwigs, Christian (1915), Salme og Sang. København.

Nygård, Frederik (1889) i Danskeren, II, København, 382-383.

Thaning, Kaj (1963), Menneske først - Grundtvigs opgør med sig selv, bind 1-3, København.

Werlauff, E. C. (1858), Historiske Antegnelser til Ludvig Holbergs atten første Lystspil, [2. stærkt forøgede udg.], København.

\section{Noter}

Denne artikel er en bearbejdet version af en forelæsning holdt på Vartov, den 26. marts 2007, til ære for Flemming Lundgreen-Nielsen i anledning af dennes 70-års fødselsdag.

1 Denne betydning har udtrykket "gott ár" i vestnordisk sagasprog (en oplysning, jeg skylder Flemming Lundgreen-Nielsen tak for).

2 Jf. fx Grundtvigs "Høst-Sang" fra 1844 ("Nu falmer Skoven trindt om Land") (GSV IV, 50-51).

3 En datering af teksten som skrevet julenat 1825 og oplæst efter Grundtvigs prædiken ved morgengudstjenesten 1. juledag kan føres tilbage til en oplysning fra mundtlig overlevering, som grundtvigianeren Frederik Nygård har offentliggjort i tidsskriftet Danskeren, II, 1889, 382383 (SJ I, 199). Kaj Thaning har ud fra sin forståelse af juleprædikenteksten 1824 sammenholdt med prædikenen "Advents-Nat og JuleMorgen" fra 1830 forkastet Nygårds beretning og omdateret digtets tilblivelse og oplæsning til julen 1824 (Thaning 1963, 37, 69, jf. 560). Herefter har forskerne udtalt sig mere forsigtigt om tilblivelsestidspunktet (fx Thodberg i GP II, 8-9, GP III, 8; Dam 1995, 134). Det står imidlertid 
fast, at selve teksten først kendes fra trykket i Grundtvig 1830 (udgivet 21. juli 1831, jf. $S J$ I, 221).

4 Jf. fx Sl 77, 85, 89, 106.

5 Julelege havde på Grundtvigs tid unægtelig en anden betydning end den, han ønsker at lægge i dem. Fra og med Holbergtiden var de degenereret til dels pantelege af erotisk art, dels dans til juleviser, jf. Werlauff 1858 , 182-199 (med tak til Flemming Lundgreen-Nielsen for henvisningen). I Grundtvigs tolkning af julelegene ligger der et opgør med denne skik, helt på linje med Brorsons kamp imod "syndig legestue" i salmerne "Bort! verdens jule-glæde / Af hvert et huus og sind" og "I denne søde jule-tiid / bør man sig ret fornøye" (Koch 1951, 27 og 29).

6 Se til de forskellige varianter oplysningerne i GSV VI, 74.

7 Ganske vist synes Grundtvig heller ikke selv at være helt sikker på, hvad han mente, for i manuskriptet til Prøvehæftet har han i 1844 eller 1845 rettet 'vor Herre' til 'Vorherre' (GSV VI, 74, litra f til 7,3), og rettelsen er bevaret i trykket 1845 (litra g) og i 2. udg. af GSV 1868 (litra i. Igen tak til Flemming Lundgreen-Nielsen for denne henvisning).

8 Kjærgaard 2002, 103 henviser også til dette skriftsted.

9 I Egenhoendig renskrift til 1837-trykket af "Velkommen igien..." i SangVork, I, i Collinske Samling $2208^{\circ}$ er stemningsskiftet markeret med en tyk streg, som så også findes i GSV I-udgaven, men ikke i Søndags-Bog, III, 1830, ej heller i L.C. Hagens optryk af den i Historiske Psalmer og Riim til Børne-Lardom fra 1832. Den findes heller ikke i optrykket af Søndags-Bog fra $1860 \mathrm{og}$ i de senere udgaver af Historiske Psalmer og Riim 1843, 1848 og 1856 (1840-udgaven kunne jeg ikke få oplysning om), alt sammen udgaver i Grundtvigs levetid, som han formodentlig har godkendt. (Oplysningerne herom skylder jeg Flemming LundgreenNielsen samt Liselotte Larsen, Vartov-Biblioteket, tak for.) Men i FestPsalmer, 1850 og videre frem, udelod Grundtvig på eget initiativ strofe 8 og også strofe 3, og i denne forkortede udgave stod salmen så i alle senere salmebøger indtil Den Danske Salmebog 1953, jf. Kjærgaard 2002, 102. Dermed ødelagde Grundtvig sin egen salme, for begge strofer er trods stemningskift i strofe 8 fuldt integreret i hele salmen og kan ikke undværes. Stryger man fx strofe 3, bliver man også nødt til at stryge de indledende to strofer.

10 Det henvises der med rette til i Ludwigs 1915, 81.

11 Jf. Grundtvig 1840-42, 370-457, 3. kapitel "Det Christelige Liv som et Christus-Liv". 